African Journal of Biomedical Research, Vol. 10 (2007); 217 - 222

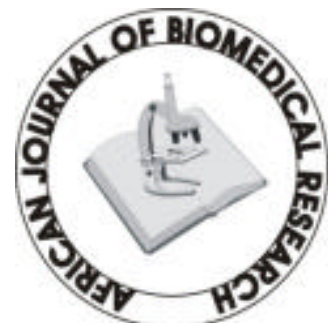

Full-text available at http://www.ajbrui.com http://www.bioline.br/md http://www.ajol.com

Received:

May 2007

Accepted (Revised) : July 2007

Published

September 2007
Full Length Research Article

\section{Plasma Copper Status in Hypercholesterolemic Patients}

\section{Soyinka, Oluwatosin $\mathrm{O}^{1} *$; Anetor John $\mathrm{I}^{2}$; Ogundaunsi Omobola $\mathrm{A}^{\mathbf{1}}$; Adeniyi, Francis $\mathrm{A}^{\mathbf{2}}$}

${ }^{1}$ Department of Chemical Pathology and Immunology, OACHS, Olabisi-Onabanjo University, Sagamu campus, Ogun State, Nigeria.

${ }^{2}$ Department of Chemical Pathology and Immunology, University of Ibadan, Nigeria.

\section{ABSTRACT}

There has been inconsistent association between low copper (Cu) status and hypercholesterolemia (Hypercholesterolemia is a known risk factor in coronary heart disease). Most of these earlier studies have been predominantly in experimental models; very few reports have examined human subjects. We investigated the relationship between $\mathrm{Cu}$ status and hypercholesterolemia in human subjects and if this relationship is established it may be amenable to nutritional interventions. Seventy four (74) randomly selected plasma samples from patients on which cholesterol (Chol) estimations had been previously performed were included. The plasma samples were classified into three (3) categories according to the cholesterol concentration based on the reference range at UCH, Ibadan as at the time of analysis. The study groups included the following, hypercholesterolemic group (group1) (Chol level, > 250mg/dl), normocholesterolemic group (group2) (Chol level, $150=250 \mathrm{mg} / \mathrm{dl}$ ); and hypocholesterolemic group (group 3) (Chol level, 87$149 \mathrm{mg} / \mathrm{dl}$ ). The mean values of $\mathrm{Cu}$ in groups 1,2 , 3 were $103.39 \pm 8.58 \mu \mathrm{g} / \mathrm{dl}$, $122.67 \pm 14.69 \mu \mathrm{g} / \mathrm{dl}$ and $123.82 \pm 10.15 \mu \mathrm{g} / \mathrm{dl}$ respectively. The mean concentration of $\mathrm{Cu}$ in hypercholesterolemia was significantly different from the normocholesterolemia ( $p<0.0001)$ and the hypocholesterolemia $(p<0.0001)$ respectively. The plasma $\mathrm{Cu}$ level of the hypercholesterolemic group was the lowest; while the levels in the normocholesterolemic and the hypocholesterolemic groups were similar. The low level of $\mathrm{Cu}$ in the hypercholesterolemic group was significantly lower than the levels in groups 2 and 3 ( $p<0.0001)$ in both cases. There was a significant inverse correlation between cholesterol and Cu levels ( $r=-0.4909 ; p<$ 0.0001). These data support some previous reports that hypercholesterolemia is associated with decrease $\mathrm{Cu}$ status and this may be manipulated to control hypercholesterolemia and associated disorders.

(Afr. J. Biomed. Res. 10: 217-222)

Key Words:

hypercholesterolemia, hypocholestrolemia, normocholesterolemia, copper, coronary heart disease.

*Address for Correspondence: Tel:+234 8037123058;e-mail: tosinsoyinka @ yahoo .com

Abstracted by:

African Index Medicus (WHO), CAB Abstracts, Index Copernicus, Global Health Abstracts, Asian Science Index, Index

Veterinarius, Bioline International , African Journals online 


\section{INTRODUCTION}

The transition metal copper is an essential human micronutrient for enzymes that catalyze oxidation - reduction reactions (Linder and Hazegh-Azam, 1996). Copper has also been described as an antioxidant nutrient for cardiovascular health (Allen et al, 1994). One of the nutrients associated with copper metabolism is cholesterol. The latter plays a central role in many biomedical processes but is best known for its association with cardiovascular disease. Hypercholesterolemia is considered a major risk factor for the development of atherosclerosis (Gotto, 1986). Diets low in copper also has been suggested as an explanation for much of the epidemiology and pathophysiology of ischemic heart disease (Klevay, 2000). For some authors, absolute copper deficiency could be a risk factor in the etiology of cardiovascular diseases by altering lipid metabolism (Thuiller- Jeteau et al, 1987). Furthermore copper deficiency was claimed to be the only nutritional insult that elevates cholesterol (Klevay et al, 1984). Hypercholesterolemia was also found to be one of the similarities that exist between animals deficient in copper and people with ischemic heart disease (Klevay, 1983). Copper deficiency is therefore offered as the simplest and most general explanation for ischemic heart disease (Klevay, 2000).

A substantial decrease in liver copper concentration has been demonstrated after feeding rats with a cholesterol-rich diet (Abu-el-Zahab 1991). Moreover feeding rats a Copper - deficient diet resulted in hypercholesterolemia (Al-Othman et al 1994; Carr et al 1990). Biochemical correlate of copper insufficiency included hypercholesterolemia when over 30 men and women were depleted of copper carefully with diets made with conventional foods containing 0.65 to $1.02 \mathrm{mg} /$ day (Klevay et al, 1984; Reiser et al 1987). Copper deficiencies from several species have produced hypercholesterolemia in at least 22 independent laboratories worldwide ( klevay, 2000). Many people consume slightly less than the "safe and adequate range" of copper, $1.5-3.0 \mathrm{mg} /$ day though, frank copper deficiency is uncommon. Deficiency can occur in people using zinc supplement without increasing copper intake because zinc interferes with copper absorption (Sandstead, 1995).

The study aims at investigating copper status in hypercholesterolemic patients and to determine the relationship between copper and cholesterol metabolism, and if this relationship is established copper deficiency may be amenable to nutritional interventions.

\section{MATERIALS AND METHODS}

\section{Selection of Subjects.}

The study was carried out on seventy-four (74) randomly selected plasma samples obtained from the Clinical Chemistry Laboratory of the Department of Chemical Pathology, University College Hospital (UCH), Ibadan. These samples were among the biological materials of subjects referred to the laboratory for cholesterol estimation. The details of the patients' states of health, features such as age and sex were then traced to their case records. Some of these could not be retrieved. The samples were classified into three groups. Group 3 was made up of samples with cholesterol values less than $150 \mathrm{mg} / \mathrm{dl}$ (hypocholesterolemic) while group 2 consisted of samples with cholesterol values within the local reference range as at the time of analysis; these are values between 150 and $250 \mathrm{mg} / \mathrm{dl}$ (normocholesterolemic). Group 1 included samples with cholesterol values greater than $250 \mathrm{mg} / \mathrm{dl}$ (hypercholesterolemic). Group 1, the hypercholesterolemic group, serves as the study group while groups 2 and 3 were included for comparison.

\section{Methods}

Plasma cholesterol estimation was performed using essentially the enzymatic method of Trinder (1969) on Boehringer Mannheim Hitachi 704 Autoanalyser. (Boehringer Mannheim GmbH. D-68298 Mannheim Germany). Plasma copper level was determined using atomic absorption spectrophotometer (AAS), on Pye Unicam S.P. 90A series 2 (Pye Unicam Ltd., 
Cambridge, England). Plasma total protein level was determined by the Biuret method (Reinhold, 1953) and albumin level in plasma was estimated using the method of Doumas et al (1971). Statistical analyses were carried out using Statpac Gold Statistical Analysis package. Student's t- test was used to compare means of two groups, while ANOVA was used to compare means involving three groups. Pearson's correlation coefficient was used to establish relationship between variables. Values of $\mathrm{P}<0.05$ were considered statistically significant.

\section{RESULTS}

Table1 shows the mean copper levels in hypercholesterolemic group 1, normocholesterolemic group 2 and hypo-cholesterolemic group 3 . The mean copper level ranges from $103.39 \pm 8.58 \mu \mathrm{g} / \mathrm{dl}$ to $123.85 \pm 10.75 \mu \mathrm{g} / \mathrm{dl}$. Group 1 demonstrated the lowest mean copper value while group 3 demonstrated the highest mean copper value, thus displaying an interesting trend of decrease in mean plasma copper level from group 3 to1. When the mean copper levels of the various groups were compared, a highly significant difference was exhibited $(\mathrm{P}<0.0001)$. Table 2 shows further comparison of the mean copper level between groups 1 and 2 , a significant difference was observed, $p<0.0001$. Similarly a significant difference was observed between groups 1 and 3 $p<0.0001$. Correlation of copper with cholesterol exhibited a highly significant inverse relationship $(\mathrm{r}=-0.4909 ; \mathrm{p}<0.0001)$ as shown in table 3. Table 4 shows the correlation between Age, cholesterol and Copper.

Table 1

Comparison of copper levels among hypercholesterolemic, normocholesterolemic and hypocholesterolemic subjects (groups 1, 2 and 3)

\begin{tabular}{|c|c|c|c|}
\hline $\begin{array}{l}\text { Groups/ } \\
\text { sample No }\end{array}$ & $\begin{array}{l}\text { copper } \\
\text { level } \\
(\mu \mathrm{g} / \mathrm{dl})^{*}\end{array}$ & $\begin{array}{l}\mathbf{F} \\
\text { value }\end{array}$ & $\begin{array}{l}\mathbf{P} \\
\text { value }\end{array}$ \\
\hline $\begin{array}{l}\text { hypercholesterolemic } \\
\text { (Group 1) }(\mathrm{n}=18)\end{array}$ & $\begin{array}{l}103.39 \\
\pm 8.58 \\
\end{array}$ & \multirow{3}{*}{15.85} & \multirow{3}{*}{$\begin{array}{l}\mathrm{p}< \\
0.0001\end{array}$} \\
\hline $\begin{array}{l}\text { normocholesterolemic } \\
(\text { Group 2) }(n=43)\end{array}$ & $\begin{array}{l}122.67 \\
\pm 14.69\end{array}$ & & \\
\hline $\begin{array}{l}\text { hypocholesterolemic } \\
\text { (Group3) }(\mathrm{n}=13)\end{array}$ & $\begin{array}{l}123.82 \\
\pm 10.15\end{array}$ & & \\
\hline
\end{tabular}

* Values are mean $\pm \mathrm{SD} ; \mathrm{n}=$ sample number

Table 2

Comparison of copper levels between hypercholesterolemic and normocholesterolemic subjects; and between hypercholesterolemic and hypocholesterolemic subjects.

\begin{tabular}{llll}
\hline Groups & $\begin{array}{l}\text { Copper } \\
(\mu \mathrm{g} / \mathbf{d l}) *\end{array}$ & $\begin{array}{l}\text { t- } \\
\text { value }\end{array}$ & P value \\
\hline $\begin{array}{l}\text { Hypercholesterolemic } \\
\text { (Group 1) }\end{array}$ & $\begin{array}{l}103.39 \\
\pm 8.58\end{array}$ & & \\
& & 5.35 & $\mathrm{p}<0.0001$ \\
$\begin{array}{l}\text { Normocholesterolemic } \\
\text { (Group 2) }\end{array}$ & 122.67 & & \\
\hline $\begin{array}{l}\text { Hypercholesterolemic } \\
\text { (Group1) }\end{array}$ & 103.39 & & \\
& \pm 8.58 & & \\
$\begin{array}{l}\text { Hypocholesterolemic } \\
\text { (group3) }\end{array}$ & 123.82 & & $\mathrm{p}<0.0001$ \\
\hline
\end{tabular}

* Values are mean \pm SD

Table 3

Simple Correlation matrix between cholesterol, copper, total protein and Albumin

\begin{tabular}{llll}
\hline Biochemical variables & Cholesterol & Total Protein & Albumin \\
\hline Total Protein & $\mathrm{r}=0.3131$ & & \\
\cline { 2 - 4 } & $\mathrm{P}=\mathrm{NS}(0.007)$ & $\mathrm{r}=0.3232$ & \\
\hline Albumin & $\mathrm{r}=0.0782$ & $\mathrm{P}=\mathrm{NS}(0.005)$ & $\mathrm{r}=-0.0601$ \\
\cline { 2 - 4 } & $\mathrm{P}=\mathrm{NS}(0.508)$ & $\mathrm{r}=0.1111$ & $\mathrm{P}=\mathrm{NS}(0.611)$ \\
\hline Copper & $\mathrm{r}=-0.4909$ & $\mathrm{P}=\mathrm{NS}(0.346)$ & $\mathrm{P}=0.0000 *$ \\
\cline { 2 - 4 }
\end{tabular}

$r=$ correlation coefficient $; P=P$-value; $*=$ Significant $;$ NS= Not-significant 
Table 4

Correlation between Age, cholesterol and Copper

\begin{tabular}{lll}
\hline Age & Cholesterol & Copper \\
\hline Age & $\mathrm{r}=0.0138$ & $\mathrm{r}=03795$ \\
\cline { 2 - 3 } $\begin{array}{l}\text { Mean }=42.23 \pm \\
\text { 15.05) }\end{array}$ & $\mathrm{P}=\mathrm{NS}$ & $\mathrm{P}=\mathrm{NS}$ \\
${;} P=P$-value $; }$ & NS $=$ Not-significant
\end{tabular}

\section{DISCUSSION}

Association between low copper status and hypercholesterolemia has been documented consistently in experimental models (Allen and Klevay 1978; Harvey and Allen 1981; Croswell and Lei, 1985; Carr et al 1990; Al- Othman et al 1994; Bureau et al 2003). Clinical pursuits to ascertain similar effects (or otherwise) among patients that are hypercholesterolemic is scanty.

This study was designed therefore to examine copper status in hypercholesterolemic patients so as to provide a basis for consideration of nutritional interventions, which have been suggested by some investigators (AlarconCorredor et al 2004; Galhardi et al, 2005). This study is important because hypercholesterolemia is a risk factor of coronary heart disease, which is a leading cause of death among many populations (Anon, 1967; Gotto, 1986; Strain 1994; Anon, 2000; AIHW, 2002). It is therefore a relevant factor in the pursuit of strategies for prevention or reduction of coronary heart disease through nutritional interventions.

The inverse relationship between copper and cholesterol levels observed in this study is consistent with other studies (Klevay et al 1984; Klevay 1990a, 1990b, and 2000). Klevay has consistently demonstrated an inverse relationship between cholesterol and copper metabolism. However several other investigators have not been able to reproduce this association. Thuiller Jeteau et al (1987) reported increased $\mathrm{Cu}$ status in hypercholesterolemia. Abiaka et al (2003) observed that unlike in animal studies, copper excess in humans is associated with hypercholesterolemia and therefore will predispose to atherosclerosis. Aoyama et al (1999) observed that serum cholesterol did not increase in rats fed with copper-deficient diets, though copper in serum decreased markedly in rats. Bergomi et al (1997) found an inverse correlation between lysyl oxidase activity in serum and both systolic and diastolic blood pressure in untreated, mild essential hypertension. This can be said to be indirectly consistent with this study because lysyl oxidase is a copper enzyme (among many others) Klevay (2000) and hypercholesterolemia is a risk factor of hypertension.

From past studies, copper deficiency developed in experimental animals and also in man, had resulted in hypercholesterolemia (Klevay et al, 1984; 2000). Copper supplementation had also been found to reduce total cholesterol in rats (Galhard et al 2005). According to AlarconCorredor et al 2004, copper supplementation decreased serum total cholesterol in man. This study had demonstrated reduced copper status in hypercholesterolemia, hence it substantiates the fact that reduced copper status is associated with hypercholesterolemia. There is therefore need to establish if with adequate copper nutriture, hypercholesterolemia can be prevented, thus probably reducing the risk of coronary heart disease.

One of the suggested mechanisms of action between reduced copper status and hypercholesterolemia is that copper deficiency increases the activity of $\beta$-hydroxyl- $\beta$-methylglutarylCoA (HMG-CoA) reductase, This enzyme catalyzes the rate limiting step in the biosynthetic pathway of cholesterol from acetyl-CoA. The increased activity of the enzyme in the liver in copper deficient rats corresponds with increased cholesterogenesis. It was thought that more of this newly synthesized cholesterol may be channeled for the synthesis of lipoproteins and their subsequent release into circulation thus causing increase in plasma level. (Valzala et al 1987).

The results of this study show an inverse relationship between copper and cholesterol levels. The findings support the hypothesis that hypercholesterolemia is associated with reduced copper status.

\section{REFERENCES}

Abiaka, C; Olusi, S; Al-Awadhi, A. (2003): Serum microminerals and the indices of lipid metabolism in an apparently healthy population. J. Clin. Lab. Anal. 17 
(2), 61-5

Abu -el-Zahab, H.S., Abdel-Aal, W.E., Awadallah, R., Mikhail, T.M., and Zakaria, K. (1991): The correlation between serum total cholesterol and some trace elements in serum, liver and heart of rats fed high cholesterol. Nahrung 35(8), 827-34

Alarcon-Corredor, O.M., Guerrero, Y., Ramirez de fernandez ., D'Jesus I., Burguera, M et al (2004): Effects of copper supplementation on lipid profile of Venezuelan hyperlipedemic patients. Arch Latinoam Nutr. 54 (4):413-8

Allen, K.G. and Klevay, L.M. (1994): Copper: an antioxidant nutrient for cardiovascular health. Curr. Opin. Lipidol. 5 (1): 22-8

Allen, K. G. D. and Klevay, L.M. (1978): Copper deficiency and cholesterol metabolism in the rat. Atherosclerosis 31, 259-271.

Al-Othman, A.A., Rosenstein, F., and Lei, K.Y. (1994): Pool size and concentration of plasma cholesterol are increased and tissue copper levels are reduced during early stages of copper deficiency in rats. J. Nutr. 124, 628-635.

Anon (2000): Cardiovascular disease ranks as the first cause of death in Spain. Rev Esp Salud Publica 74 (3), 215-53.

Anon. (1967): Vital Statistics of the United States. Mortality, Washington: U.S. Dept. Health, Educ. Wefare, 1969, vol. 2, Part A, Tables 1-7.

Aoyama Y, Takagi M, Yoshida A. (1999) Lipid alterations in the liver and serum of rats in histidineexcess and copper deficiency. J. Nutr. Sc. Vitaminol (Tokyo) 45 (6), 773-83

Australian Institute of Health and Welfare (AIHW) (2002): Epidemic of coronary heart disease and its treatment in Australia . Canberra Report No.: AIHW cat. No. CVD $21 . \quad$ Available at:http://www.aihw.gov.au/publications/index.cfm/find/ epidemic $\% 20$ of $\% 20$ coronary $\% 20$

heart\%20disease Accessed July 2004

Bergomi, M., Rovesti S., Vinceti M., Vivoli R., Caselgrandi, E., Viroli, G. (1997): Zinc and copper status and blood pressure. J. Trace Elem. Med. Biol. 11, 166-169.

Bureau, I., Gueux, E., Mazur, A., Rock, E., Roussel, $A$ and Rayssiguier Y (2003): Female Rats are protected against oxidative stress during copper deficiency. Journal of the American College of Nutrition 22 (3), 239-246

Carr, T.P., and Lei, K.Y. (1990): High-density lipoprotein cholesteryl ester and protein catabolism in hypercholesterolemic rats induced by copper deficiency. Metabolism 39, 518-524.

Croswell S.C. and Lei, K.Y. (1985): Effect of Copper
Deficiency on the Apolipoprotein- E- rich High Density Lipoproteins in Rats. J. Nutr. 115:473-482.

Doumas, B. T., Watson, W and Biggs, H. G. (1971): Albumin standards and the measurement of serum albumin with bromocresol green. Clinica Chim. Acta. 31, 87-96.

Galhardi C.M., Diniz, Y.S., Rodrigues, H.G., Faine, L.A., Burneiko, R.C., Ribas, B.O. and Novelli, E.L. (2005): Beneficial effects of dietary copper supplementation on serum lipids and antioxidant defenses in rats. Ann. Nutr. Metab. 49, 283-8

Gotto AM. Jr. 1986: Interaction of the major risk factors for coronary heart disease. Am. J. Med. 14, 80 (2A): 48-55

Harvey, P.W. and Allen, K.G.D. (1981): Decreased plasma lecithin: cholesterol acyltransferase activity in copper deficient rats. J. Nutr. 111, 1855-8.

Klevay L.M. 1990a: Ischemic heart disease as copper defiency. Kies C. eds. Copper Bioavailability and metabolism Adv. Exp. Med. Biol. 258, 197-208. Plenum Press New York, NY.

Klevay LM, Inman L., Johnson LK, Lawler M., Mahaiko JR., Milne DB., Lukaski HC., Bolonchuk W., Sandstead HH (1984): Increased cholesterol in plasma in a young man during experimental copper depletion. Metabolism 33,1112-1118.

Klevay LM. (2000): Dietary copper and risk of coronary heart disease. American journal of clinical nutrition 71 (5), 1213-1214.

Klevay LM. (2000): Trace element and mineral nutrition in disease: ischemic heart disease. In: Bogden JD, Klevay LM, eds. Clinical nutrition of the essential trace elements and minerals: the guide for health professionals. Totowa, NJ: Humana Press Inc: 251-71.

Klevay, L.M. (1983): Copper and Ischemic heart disease Biol. Trace Element Res. 5: 245-255

Klevay, L.M. (1990b): Ischemic heart disease: toward a unified theory. Lei. K.Y. Carr T.P. eds. Role of copper in lipid metabolism/ TITLE> 233- 267 CRC Press Bocs Raton, FL.

Linder MC, Hazegh-Azam M. (1996): Copper biochemistry and molecular biology Am. J. Clin. Nutr. 63,797S-811S

Reinhold. J.G. (1953): Standard method of clinical chemistry, $1^{\text {st }}$ ed. (Reiner, M. Ed.). New York. Academic Press. 1:88.

Reiser S., Powell A., Yang CY., Canary JJ (1987): Effect of copper intake on blood cholesterol and its lipoprotein distribution in men. Nutr. Rep. Int. 36, 641649.

Sandstead HH. (1995): Requirements and toxicity of essential trace elements, illustrated by zinc and copper. Am. J. Clin. Nutr. 61: 621S-624S. 
Strain (1994): Newer aspects of micronutrients in chronic disease: copper. Proceedings of the Nutrition Society. 53, 583-598

Thuillier-Juteau Y., Jaudon M.C., Clavel J.P., Delattre J., Galli. (1987): Serum zinc and copper in hypercholesterolemia. Pathol Biol (Paris). (Apr) 35 (4): 387-90
Trinder P (1969): Ann. Clin. Biochem. 6, 24.

Valzala, P., Kurup P.A. (1987): Investigations on mechanism of hypercholesterolemia observed in copper deficiency in rats J. Biol. Sci. 12, 137.

Wapnir, R.A. (1998): Copper absorption and bioavailability. Am. J. Clin. Nutr. 67 (Suppl.), 1054S1060S. 